\title{
Deafness Genes in Israel: Implications for Diagnostics in the Clinic
}

\author{
ZIPPORA BROWNSTEIN AND KAREN B. AVRAHAM
}

Department of Human Molecular Genetics and Biochemistry, Sackler School of Medicine, Tel Aviv University, Tel Aviv, 69978 Israel

\begin{abstract}
The identification of the molecular basis of deafness in the last decade has made a remarkable impact on genetic counseling and diagnostics for the hearing impaired population. Since the discovery of the most prevalent form of deafness associated with mutations in the GJB2 (connexin 26) gene, many other genes have been found worldwide, with a subset of these, including unique mutations, in Israel. Here, we review the current status of deafness genes in Israel and report one known mutation in a syndromic form of deafness, Usher syndrome, described in the Jewish Israeli population for the first time. In the future, the identification of specific mutations may be relevant for specific types of treatment. (Pediatr
\end{abstract} Res 66: 128-134, 2009)

\section{Hereditary Hearing Loss}

Patients with hearing loss (HL) and parents of hearing impaired children often wish to discover the cause of this most common sensory characteristic, one in which both medical geneticists and otolaryngologists are involved. The presence of a particular mutation may aid in making decisions regarding treatments and interventions, as well as prognosis for the future. Nonsyndromic deafness affects approximately 1 in 1000 newborns and $4 \%$ of people aged younger than 45 y (1). This number rises dramatically in regions where consanguinity is an acceptable social custom and is encouraged $(2,3)$. Progressive HL affects an even greater proportion of the population. Approximately one quarter of persons develop HL by the age of 65 (1) and $~ 50 \%$ of persons by age 80 (4). HL is estimated to be inherited or has a genetic basis in approximately $60 \%$ of cases (5). Genetic HL includes $\sim 30 \%$ syndromic HL (SHL), associated with other clinical findings such as blindness and neurologic defects, and 70\% non-SHL (NSHL), where $\mathrm{HL}$ is an isolated characteristic (6).

Because in diverse populations different genes are involved, genetic evaluation of each population should be based on an empirical study of that population. In this article, we review the genes involved in HL in Jewish Israeli samples, and we use the empirical data to develop a genetic testing algorithm for use in the Israeli population. We have updated the number of patients screened for connexin 26 mutations since this data

Received January 29, 2009; accepted March 13, 2009.

Correspondence: Zippora N. Brownstein, Ph.D., Department of Human Molecular Genetics and Biochemistry, Sackler School of Medicine, Tel Aviv University, Tel Aviv 69978, Israel; e-mail: brownste@post.tau.ac.il

Supported by the Grants NIH R01 DC005641, the European Commission FP6 Integrated Project EUROHEAR LSHG-CT-20054-512063, and the Hirschfield Foundation.

Supplemental digital content is available for this article. Direct URL citations appear in the printed text and are provided in the HTML and PDF versions of this article on the journal's Web site (www.pedresearch.org). were published in 2000 (7). We also report a mutation in the harmonin gene in Usher syndrome (USH), not previously detected in the Jewish population in Israel. Although the particular list of genes may be different in other populations, the general scheme of the algorithm is relevant to other populations as well.

SHL includes nearly 400 forms of deafness combined with other clinical findings [(6); Hereditary Hearing Loss Homepage, available at http://webh01.ua.ac.be/hhh/ and Online Mendelian Inheritance in Man, available at http://www. ncbi.nlm.nih.gov/sites/entrez?db=omim]. The severity of $\mathrm{HL}$ varies between and within syndromes, and some of the syndromes are rare. However, HL is most significant in several well-characterized syndromes. In the deaf Jewish Israeli sample, mutations were detected in two genes involved in USH. USH is defined by congenital NSHL, retinitis pigmentosa (RP), and vestibular dysfunction, and it accounts for more than $50 \%$ of the deaf-blind population (8), approaching a prevalence of 1 in 10,000 between the ages of 30 and 49 (9).

Nonsyndromic deafness is represented by extreme genetic heterogeneity, as up to 130 loci have been mapped and 45 nuclear genes have been identified to date, including $27 D F N B$ (autosomal recessive) genes, 22 DFNA (autosomal dominant) genes ( 7 genes are involved in both dominant and recessive forms), $1 \mathrm{X}$-linked gene, and 2 mitochondrial genes (http:// webh01.ua.ac.be/hhh/). The most common form of NSHL is inherited in an autosomal recessive mode, which accounts for up to $80 \%$ of cases (10). Autosomal dominant inherited NSHL is involved in $20 \%$ of cases and X-linked in $1 \%$. Mitochondrial HL has been described in approximately 1 in 500 of NSHL in Europeans $(11,12)$ and is higher in Spain $(5,13)$. Autosomal recessive NSHL is mostly due to cochlear defects (sensorineural deafness) (14), and in the majority of cases, it is congenital profound, whereas autosomal dominant $\mathrm{HL}$ is mostly postlingual and progressive (10).

\section{Deafness Genes in the Jewish Israeli Population}

To achieve our goal in defining the number of genes associated with deafness in the Jewish Israeli population in Israel, we worked with most genetic centers in Israel. The project was approved by the National Helsinki Committee for

\footnotetext{
Abbreviations: EVA, enlarged vestibular aqueduct; HL, hearing loss; NSHL, nonsyndromic hearing loss; RP, retinitis pigmentosa; USH, Usher syndrome
} 
Human Genetic Research of the Israel Ministry of Health in a multicenter study, including the Haim Sheba Medical Center, Rabin Medical Center, Hadassah Medical Center, Sourasky Medical Center, and the Wolfson Medical Center. Blood samples were obtained after informed consent from each individual and, in case of individuals under 18 , from their parents.

Overall, 230 unrelated deaf Israeli Jews were investigated for deafness-causing genes. All subjects were tested for GJB2 mutations by sequencing the coding exon of the gene. The other genes involved in deafness in this population were screened in all subjects in whom GJB2 mutations were excluded. Some of the subjects belonged to large families with many deaf family members. Several such families were ascertained and genome scans were conducted, leading to mapping or cloning of the genes involved in deafness. Most of the resulting data were published previously and references are provided while describing the genes involved. A harmonin mutation, previously undetected in the Israel Jewish population, was identified in the course of this study (see later).

Anonymous DNA samples from hearing Jews of all ethnic groups were obtained from the Sheba Medical Center and from the Rabin Medical Center and used as controls. In the Jewish Israeli population, as in many populations in the world, the most common gene involved in $\mathrm{HL}$ is the GJB2 gene encoding the connexin $26(\mathrm{Cx} 26)$ protein (7). We found that mutations only in GJB2 are associated with $27 \%$ of congenital $\mathrm{HL}$ in our Israeli sample (Table 1). Thus far, mutations in four additional genes are known to lead to NSHL in the Jewish Israeli population, among which is $G J B 6$, encoding connexin 30 (Cx30) (15). Both the connexin encoding genes, GJB2 and GJB6, are involved in $31 \%$ of NSHL in the Jewish Israeli population studied. Two more genes, MYO3A (encoding myosin IIIA) (16) and SLC26A4 (encoding pendrin) (17), are involved in autosomal recessive deafness, and one gene, POU4F3 (18), is associated with autosomal dominant HL. In addition, one dominant gene has been mapped for otosclerosis, OTSC4 (19). However, according to our findings, the mutations in these six genes are involved in only approxi- mately one third of the genetic deafness cases in the portion of the Israeli population studied. For recessive NSHL, a minimum estimate of eight to nine genes was calculated in the general deaf Israeli population (20), with a range of 7-22 loci within and between intraethnic and interethnic matings, respectively, indicating that in different ethnic groups, different loci may exist. We describe four recessive genes causing HL in less than half of our sample, suggesting that there is still more than half way to go to identify all the genes involved in deafness in the Jewish Israeli population.

\section{Autosomal Recessive Genes GJB2 and GJB6}

GJB2 (NM_004004.4) was the first autosomal recessive gene found to cause NSHL, discovered in 1997. This was especially compelling because it has turned out to be the largest single contributor to prelingual NSHL. The GJB2 gene maps to chromosome 13q11-q12 and contains two exons of which only one is coding. GJB2 encodes Cx26, a gap junction protein of 226 amino acids. Cx26 belongs to a family of more than 20 members that share a common structure of four transmembrane segments. Most cell types express more than one connexin species, which may form homomeric or heteromeric connexons. In the auditory system, intercellular channels are formed predominantly by $\mathrm{Cx} 26$ but also by $\mathrm{Cx} 30$, Cx31, and Cx43 (21,22). Cx26 seems to be involved in maintaining a high-extracellular $\mathrm{K}$ concentration in the endolymph by facilitating the circulation of $\mathrm{K}+$ ions $(23,24)$.

GJB6 (NM_001110219.1) has five exons, of which only one is coding. The Cx30 protein of 261 amino acids, encoded by this gene, shares $76 \%$ identity with human Cx26 (25). GJB6, as GJB2, maps to $13 \mathrm{q} 11-\mathrm{q} 12$ and colocalizes with $G J B 2$ in the same inner ear structures: in the supporting cells of the organ of Corti, in the stria vascularis, and in the spiral ligament (22). Connexons composed of $\mathrm{Cx} 26$ can bind connexons composed of $\mathrm{Cx} 30$ to form heterotypic gap junction channels (26).

Table 1. GJB2 (Cx26) and GJB6 (Cx30) mutations in the Jewish Israeli population (70 GJB2/GJB6 out of 230 NSHL probands)

\begin{tabular}{|c|c|c|c|c|c|}
\hline & Mutations & $\begin{array}{l}\text { Number of } \\
\text { individuals }\end{array}$ & Ethnic group & $\begin{array}{c}\text { Frequency among } \\
\text { GJB2/GJB6 deafness }(\%)\end{array}$ & $\begin{array}{c}\text { Frequency among } \\
\text { NSHL }(\%)\end{array}$ \\
\hline \multirow{3}{*}{$\begin{array}{l}\text { Homozygotes for } G J B 2 \\
\text { mutations }\end{array}$} & c.35delG & 16 & All & 22.9 & 7.0 \\
\hline & c.167delT & 21 & Ashkenazi & 30.0 & 9.1 \\
\hline & c.51del12insA & 3 & Buchari & 4.3 & 1.3 \\
\hline \multirow[t]{6}{*}{$\begin{array}{l}\text { Compound heterozygotes for } \\
\text { GJB2 mutations }\end{array}$} & c.35delG/c.167delT & 14 & $\begin{array}{l}\text { Ashkenazi, Ashkenazi-other, } \\
\text { Syrian }\end{array}$ & 20.0 & 6.1 \\
\hline & c.35delG/p.L90P (c.269 T ${ }^{\circledR}$ C) & 3 & Iraqi-other & 4.3 & 1.3 \\
\hline & p.L90P/IVS1+1(G->A) & 1 & Iraqi & 1.4 & 0.5 \\
\hline & c.51del12insA/p.W24X & 1 & Buchari & 1.4 & 0.5 \\
\hline & c.35delG/p.R32C & 1 & Ashkenazi & 1.4 & 0.5 \\
\hline & p.V37I/c.35delG & 1 & Ashkenazi & 1.4 & 0.5 \\
\hline $\begin{array}{l}\text { Deafness due to } G J B 2 \\
\text { mutations }\end{array}$ & & 61 & & 87.1 & 26.8 \\
\hline $\begin{array}{l}\text { Homozygotes for } G J B 6 \\
\text { mutations }\end{array}$ & $\operatorname{del}(G J B 6-\mathrm{D} 13 \mathrm{~S} 1830)$ & 1 & Ashkenazi & 1.4 & 0.5 \\
\hline Double heterozygotes: & del(GJB6-D13S1830)/c.35delG & 3 & Ashkenazi & 4.3 & 1.3 \\
\hline GJB2/GJB6 & $\operatorname{del}(G J B 6-\mathrm{D} 13 S 1830) / \mathrm{c} .167 \mathrm{delT}$ & 5 & Ashkenazi & 7.1 & 2.2 \\
\hline $\begin{array}{l}\text { Total deafness due to } \\
\text { GJB2/GJB6 mutations }\end{array}$ & & 70 & & 99.9 & 30.8 \\
\hline
\end{tabular}


More than 100 mutations in GJB2 (the Connexin-Deafness Homepage, http://davinci.crg.es/deafness/) are responsible for up to $50 \%$ of severe to profound prelingual recessive deafness in several worldwide populations $(27,28)$. In Israel, in 2000, GJB2 was reported to be involved in $38.7 \%$ of the general deaf Israeli population (7) and for $70.4 \%$ of the deaf Ashkenazi Jews (29). In 2001, Lerer et al. (29) identified a GJB6 deletion in the Ashkenazi Jewish population, found on one allele in conjunction with a GJB2 mutation. The same GJB6 deletion of $342 \mathrm{~kb}$ was reported in Spain (31). The deletion did not directly affect the coding region of $G J B 2$, but truncated the adjacent GJB6 gene, which encodes Cx30 (30-32), and it has been shown in skin that this deletion abolishes GJB2 expression, probably by deleting a regulatory element (33). The GJB6 deletion was found to accompany in trans, the only GJB2 mutant allele in heterozygous affected subjects (double heterozygosity), and it was also found in homozygosity in several cases worldwide, including in 1 individual in Israel $(15,31,32)$. Double heterozygotes for $G J B 2$ and $G J B 6$ mutations manifest the same phenotypes as homozygotes for $G J B 2$ as well as homozygotes for $G J B 6(15,30,31)$. This deletion, named del(GJB6-D13S1830), was the accompanying mutation in $50 \%$ of the heterozygotes with only one GJB2 mutant allele in different world populations (31) and in 36\% (8 of 22) of the Jewish Cx26 heterozygotes in our sample.

In our study, out of 230 Israeli probands screened for mutations in GJB2 and GJB6, 61 (27\%) were homozygotes or compound heterozygotes for 8 mutations in GJB2 and 22 were heterozygotes. Eight of 22 GJB2 heterozygotes (36\%) were double heterozygotes $G J B 2 / G J B 6$, and one was homozygous for the del(GJB6-D13S1830) mutation. Combining the GJB2 and GJB6 mutations, the estimated prevalence of NSHL involving connexins is $31 \%$, lower than the $38 \%$ reported previously (7), but still remaining the main known cause for congenital deafness among the Jews in Israel. Table 1 summarizes the GJB2 and GJB6 mutations detected in the Jewish Israeli sample.

The most common mutations in the Israeli population are the biallelic truncating mutations, c.35delG and c.167delT, and therefore, the degree of HL of most individuals with connexin-related HL ranges from severe to profound. All the deafness in which del(GJB6-D13S1830) is involved is severe to profound as well. The few cases in which the nontruncating mutations p.V37I and p.L90P are associated, mild-tomoderate HL is observed (Table 2). All our findings are compatible with those of other populations, as was presented by a worldwide multicenter study comprising 1531 genetically and audiometrically documented individuals with connexin autosomal recessive HL (34).

Distinct mutations were associated with certain ethnic groups and were not detected in Jewish deaf individuals originating elsewhere, i.e. c.167delT was found mostly among Ashkenazi Jews and in several cases of deaf individuals originating in Syria; the del(GJB6-D13S1830) mutation was detected only among Ashkenazi Jews; the c.51del12insA frame shift mutation was found to be unique to Bukharan deaf Jews; whereas the p.L90P missense mutation was identified only in deaf individuals originating in Iraq. In many genetic clinical laboratories in Israel, only the c.35delG and the c.167delT mutations are screened by restriction enzyme assays. Based on our findings, it is clear that at least in some ethnic groups other mutations exist. Because the GJB2 gene has only one coding exon and the other mutations detected in Israel are also found frequently outside of the Jewish community, the complete coding region of the GJB2 gene should be sequenced as a routine, and considering ethnicity of the deaf individual, additional tests for the splice site mutation and the GJB6 deletion should be performed.

\section{Autosomal Recessive Gene MYO3A}

Myosin IIIA (MYO3A; NM_017433.4) maps to chromosome 10p11.1 and contains 35 exons (http://genome.ucsc.edu). The 1616 amino acid protein encoded by this gene belongs to the myosin superfamily. Myosins are actin-dependent motor proteins and are categorized into conventional myosins (class II) and unconventional myosins (classes I and III through $\mathrm{XV}$ ) based on their variable $\mathrm{C}$-terminal cargobinding domains. Class III myosins, expressed in photoreceptors, are hybrid motor-signaling molecules, with an $\mathrm{N}$-terminal kinase domain, highly conserved head and neck domains, and a class III-specific tail domain. Expression of this gene is highly restricted, with the strongest expression in retina and cochlea (16).

Table 2. Severity of the GJB2 and GJB6 mutations in a Jewish Israeli sample

\begin{tabular}{|c|c|c|c|c|c|c|c|c|c|c|c|}
\hline \multirow[b]{2}{*}{ Severity* } & \multicolumn{11}{|c|}{ Mutation } \\
\hline & $\begin{array}{l}\text { 35delG/ } \\
35 \mathrm{delG}\end{array}$ & $\begin{array}{l}\text { 167delT/ } \\
167 \mathrm{delT}\end{array}$ & $\begin{array}{l}\text { 35delG/ } \\
167 \mathrm{delT}\end{array}$ & $\begin{array}{c}\text { 35delG/ } \\
\Delta 30 \dagger\end{array}$ & $\begin{array}{c}\text { 167delT/ } \\
\Delta 30 \dagger\end{array}$ & $\begin{array}{l}\Delta 30 \dagger / \\
\Delta 30 \dagger\end{array}$ & $\begin{array}{l}\text { 51del12InsA/ } \\
\text { 51del12InsA }\end{array}$ & $\begin{array}{c}\text { 51del12InsA/ } \\
\text { W24X }\end{array}$ & $\begin{array}{l}\text { 35delG/ } \\
\text { L90P }\end{array}$ & $\begin{array}{c}\text { 35delG/ } \\
\text { R32C }\end{array}$ & $\begin{array}{c}\text { 167delT/ } \\
\text { V37I }\end{array}$ \\
\hline Profound & 11 & 10 & 9 & 2 & 4 & 1 & 1 & 1 & & 1 & \\
\hline Severe profound & 1 & 1 & & 1 & 1 & & & & & & \\
\hline Severe & & 5 & 1 & & & & & & & & \\
\hline Moderate severe & 1 & & 2 & & & & 1 & & & & \\
\hline Moderate & & & 1 & & & & 1 & & 2 & & \\
\hline Mild moderate & & 1 & & & & & & & & & 1 \\
\hline Mild & & & & & & & & & 1 & & \\
\hline Total & 13 & 17 & 13 & 3 & 5 & 1 & 3 & 1 & 3 & 1 & 1 \\
\hline
\end{tabular}

Subjects are classified based on audiogram data on the better performing ear.

*Profound HL, >95dB; severe HL, 71-95 dB; moderate HL, 41-70 dB; Mild HL 21-40 dB.

$\dagger$ GJB6-D13S1830. 
Three different autosomal recessive, loss-of-function mutations in $M Y O 3 A$ are involved in progressive NSHL in an extended Israeli family, originating in Mosul, Iraq (16). The HL begins in the second decade, first affects the high frequencies, and by age 50 is severe in high and middle frequencies and moderate at low frequencies. The mutations detected include a nonsense mutation c.3126T- $>$ G, p.Y1042X causing protein truncation at the junction of the head and neck domains of the myosin IIIA protein; a mutation in the splice acceptor of intron $17,1777(-12) \mathrm{G}->\mathrm{A}$, leading to deletion of exon 18 and protein truncation at codon 668 in the myosin head domain; and a mutation in the splice acceptor of intron 8 , $732(-2) \mathrm{A}->\mathrm{G}$, resulting in an unstable message, as revealed by the absence of message from this allele in carriers of the mutation. Of 18 affected individuals in this family, 7 are homozygous and 11 are compound heterozygous for pairs of mutant alleles. A genotype-phenotype correlation was observed among the deaf members of the family. Between the ages of 25 and 50, hearing across all frequencies was significantly poorer, and the rate of progress was higher among the individuals homozygous for the nonsense mutation comparing to the compound heterozygotes for the nonsense mutation and either of the splice mutations.

Among 172 Iraqi Jewish hearing controls, four (2.3\%) carried the nonsense mutation; none carried either splice mutation. None of the three mutations were observed among 96 Ashkenazi Jewish hearing controls (Table S1, Supplemental Digital Content 1, http://links.lww.com/PDR/A43).

As for the phenotypic-clinical aspect, the $M Y O 3 A$ gene is unique in that 1) mutations in this gene are involved in an uncharacteristic autosomal recessive HL, which unlike the other recessive deafness is late onset and progressive, and 2) three different $M Y O 3 A$ mutations underlies deafness in the same family. The existence of multiple MYO3A mutations in the same kindred also suggests that other mutations in this gene may be involved in recessive late onset HL.

\section{Autosomal Recessive Gene SLC26A4}

More than 100 mutations in the PDS (SLC26A4) gene are involved in both Pendred syndrome (PS) and NSHL DFNB4 associated with temporal bone abnormalities (35). The SLC26A4 gene (NM_000441.1), located on the long arm of chromosome 7 , contains 1 noncoding and 20 coding exons and encodes pendrin, a protein of 780 amino acids, expressed in various tissues, including the inner ear, thyroid, and kidney.

The HL caused by mutations in SLC26A4 is mostly congenital, nonsyndromic high frequency, but sometimes postlingual progressive SNHL and associated with malformations of the temporal bone. The temporal bone abnormalities vary, ranging from isolated enlarged vestibular aqueduct (EVA) to Mondini dysplasia, an abnormality in which the normal cochlear spiral of 2.5 turns is replaced by a hypoplastic coil of 1.5 turns. Albert et al. (35) estimated that SLC26A4 mutations are involved in $4 \%$ of NSHL, which emphasizes the importance of the molecular confirmation of the PDS gene in the diagnosis of deafness and particularly when temporal bone abnormality conditions are involved.
The c.1458_1459insT mutation of the SLC26A4 gene was detected in a Jewish Iranian proband with NSHL and EVA after excluding mutations in Cx26 (17). The deaf individual had progressive postlingual $\mathrm{HL}$ that began at age 6 and progressed to profound deafness. In his mid twenties, he underwent cochlear implantation. In his presurgery CT, EVA was observed and therefore the SLC26A4 gene was sequenced. The c.1458_1459insT mutation was detected on both alleles. The mutation causes a frameshift at position 487 in exon 13 (of 21), leading to a stop codon at position 526 in exon 14 of the SLC26A4 gene, p.Ile487TyrfsX39.

An additional 203 deaf probands, in which mutations in the connexins were excluded, were screened for the c.1458_ 1459insT mutation (17). Three individuals with Mondini dysplasia were included in this population. All 203 probands were wild type for this nucleotide. In total, the probability of the c.1458_1459insT mutation of the PDS gene, among the Jewish deaf population in Israel, is $0.5 \%$ (1 of 204). Normal hearing controls (310) were screened, including 21 of Iranian ethnic origin, and all 310 were found to be WT, i.e. no carriers of the mutation were detected (Table S1, Supplemental Digital Content 1, http://links.lww.com/PDR/A43).

\section{USH Gene $P C D H 15$}

Three clinical subtypes, USH1-3, are described based on the characteristics of deafness, vestibular involvement, and RP. Defects in protocadherin 15 (PCDH15) cause USH1F $(36,37)$. USH1 is the most common and most severe and characterized by congenital profound deafness, onset of RP in the beginning of the second decade of life, and constant vestibular dysfunction.

PCDH15 (NM_033056.3) is located on chromosome 10q11.2-q21. The PCDH15 gene contains 33 exons, one of which is noncoding, and it is predicted to encode a protein of 1955 amino acids. Mice carrying a mutation in Pcdh15 show disorganization in the placement of the stereocilia. It was suggested that $\mathrm{PCDH} 15$ plays a role in regulation of planar polarity in the sensory neuroepithelium of the inner ear. Members of the cadherin superfamily are also required in the eye and inner ear for maintenance of normal function (38). Recently, $\mathrm{PCDH} 15$ has been shown to be a part of the tip link complex, together with cadherin 23 (39).

The $\mathrm{R} 245 \mathrm{X}$ mutation is caused by a $\mathrm{C}$ to $\mathrm{T}$ transition at position 733 in exon 8 of the $P C D H 15$ gene, and it leads to the substitution of an arginine by a stop codon in the extracellular, second (of 11) cadherin domain. The R245X mutation accounts for more than half $(58.3 \%)$ of USH in the Ashkenazi Jewish population. This mutation was detected only among Ashkenazi Jews and was not detected in other Jewish ethnic groups (40). In our study, Ashkenazi Jewish individuals ( $n=$ 59) diagnosed with NSHL were screened for the R245X mutation (41). Twenty of the probands were younger than $10 \mathrm{y}$, and 39 were older than $10 \mathrm{y}$. This age distinction was chosen because RP is typically diagnosed after the age of 10 (42). In the first group of children under 10, 2 of $20(10 \%)$ were homozygous for R245X. In the older group, no homozy- 
gotes were detected; but 1 of 39 (2.6\%) was heterozygous for the R245X mutation.

To determine the carrier rate, 505 DNA samples of hearing Ashkenazi Jews were screened for the R245X mutation. Five out of $505(0.99 \%)$ were heterozygous for the mutation (Table S1, Supplemental Digital Content 1, http://links.lww.com/PDR/A43). The R245X mutation was not detected among 293 nonAshkenazi Jews screened elsewhere (40), and the mutation is assumed to be a founder effect in the Ashkenazi ethnic group.

These findings led to the inevitable consequence that Ashkenazi children diagnosed with NSHL should be evaluated for the R245X mutation to determine whether they will develop RP before clinical signs of this retinal defect, detectable by fundoscopy and ERG. Habilitation can then begin before loss of vision.

\section{USH Gene USH1C (Harmonin)}

Mutations in harmonin are associated with USH1C, a subtype of USH1, and are characterized by congenital deafness, RP, and vestibular dysfunction. The USHIC gene (NM_153676.2) maps to chromosome $11 \mathrm{p} 15.1$ and contains 27 exons, encoding a protein of 899 amino acids. Mutations in USHIC, as well as mutations in myosin VIIa (MYO7A), CDH23, PCDH15, or sans lead to USH1 in humans and hair bundle disorganization in mice. It was suggested that harmonin anchors the tip link upper end (likely to be made of cadherin 23) to the stereocilia actin core, hence, playing a key role in hair bundle cohesion and proper orientation of the stereocilia; it is also involved in stereociliary elongation (43).

The c.238-239InsC mutation causes a frameshift at position 78 in exon 3 (of 27), leading to a stop codon at position 148 in exon 5 of the USHIC gene, p.Tyr78TyrfsX70 (44). Previously identified only outside of Israel $(44,45)$, this mutation was recently detected in Israel in two brothers with congenital deafness, born to unrelated Ashkenazi-Jewish parents. We describe this data here for the first time. The two children, 5- and 1-y-old, were misdiagnosed as having NSHL. Homozygosity mapping was conducted using the GeneChip Human Mapping $250 \mathrm{~K}$ Nsp Array of Affymetrix, revealing a $13.63-\mathrm{Mb}$ homozygous region on chromosome 11p15.4p15.1. Homozygosity was further confirmed by five microsatellite markers, which spanned the region (including the commercially available D11S4149, D11S4116, and D11S902; Orly Elpeleg, personal communication, Hadassah Hebrew University Medical Center, Jerusalem, Israel, 2008). Of the 174 genes in this region, the harmonin gene at chromosome 11p15.1-p14, associated with USH1C and with nonsyndromic recessive deafness (DFNB18), was a good candidate. The mutation c.238-239InsC was detected by sequencing this gene. Fundoscopy confirmed onset of RP in the older brother.

Exon 3 of the harmonin gene was sequenced in addition to 20 USH unrelated patients and none of them harbored the mutation. Normal hearing controls were screened (384), including 271 of Ashkenazi origin and 113 of non-Ashkenazi ethnic groups. No carriers of the mutation were detected (Table S1, Supplemental Digital Content 1, http://links.lww.com/PDR/A43).

Because harmonin, as PCDH15, is a subtype of USH1, in which the onset of RP is in the beginning of the second decade of life, children are often misdiagnosed as having NSHL instead of USH. Therefore, children with no family history of deafness and with no GJB2/ GJB6 mutations should be evaluated for the c.238-239InsC mutation.

\section{Autosomal Dominant Gene POU4F3}

POU4F3 is a member of the POU family of transcription factors, with expression mostly restricted to hair cells of the inner ear $(46,47)$, and it is essential for inner ear hair cell maintenance. The 2-exon POU4F3 gene (NM_002700.1) maps to chromosome $5 \mathrm{q} 31$ and encodes a protein of 338 amino acids. In hearing impaired members of one large Israeli Jewish family originating in Lybia, an 8 bp deletion was identified, starting at nucleotide 884 (884del8) of exon 2 of the POU 4F3 gene (18). The predicted result of this deletion is a frameshift beginning at the second nucleotide of codon 295 and a premature translation stop at position 302, p.Ile295ThrfsX7. The 884del8 mutation in the POU4F3 gene is associated with late onset, progressive, NSHL. This deletion leads to a frameshift, predicted to cause a stop codon to be formed prematurely in the first helix of the POU-homeodomain. Mutant POU4F3 loses most of its transcriptional activity and most of its ability to bind to DNA. Moreover, although wild-type $P O U 4 F 3$ is found exclusively in the nucleus, it was demonstrated that the mutant protein is localized both to the nucleus and the cytoplasm, where transcriptional activity cannot be carried out (48).

Affected members suffer from progressive high-tone, autosomal dominant SNHL, with onset between ages 18 and $30 \mathrm{y}$. The hearing impairment becomes more severe with time, eventually causing significant $\mathrm{HL}$ across the spectrum at all frequencies (49). Two novel missense mutations were recently discovered, in the Dutch population, with a similar phenotype to the Israeli family (50).

Twenty-seven autosomal dominant deaf screened were negative for the mutation, resulting in the prevalence of $3.5 \%$ (1 of 28) of the mutation in the POU4F3 gene among autosomal dominant HL in our study. To determine the carrier rate, 114 unrelated individuals of various North African and Middle Eastern Jewish ancestries were tested for the mutation. None of the 228 control chromosomes tested carried the $8 \mathrm{bp}$ deletion in POU4F3 found in the Jewish Lybian family.

\section{A Mapped Locus for Otosclerosis OTSC4}

Otosclerosis is a common bone disorder with a prevalence of 0.2 to $1 \%$ among adults, leading to a progressive hearing impairment that begins as a conductive HL, and might develop into a mixed to SNHL, with an autosomal dominant mode of inheritance with reduced penetrance. The age of onset for otosclerosis is usually $20-40 \mathrm{y}$ and in most cases both ears are involved, but $\mathrm{HL}$ is often asymmetric (51). A definitive diagnosis of otosclerosis can be made only by surgery, but existence of family history of the disease and some other clinical characterizations are considered sufficient to diagnose otosclerosis in a family where only some members were surgically confirmed (52-54). Both environmental and genetic factors have been implicated in otosclerosis. A 2:1 female-to-male predominance suggests hormonal involvement as well (55). 
We mapped a new otosclerosis locus, OTSC4, to chromosome 16q21-23.2 in a Yemenite Israeli family with otosclerosis (19). The hearing impairment in the family ranged from conductive to mixed- to SNHL, from unilateral to bilateral HL, with variable severity, age of onset, and progression. The considerable intersubject and interaural variability within the same family might be because of the different stages of the activity of the otosclerotic lesion, which are thought to be directly correlated to the type and severity of HL and audiogram configuration.

\section{Implications for Patients With HL}

Except for the $G J B 2 / G J B 6$ genes involved in one third of the nonsyndromic deaf population of our study, all the other deafness genes are of low prevalence, frequently detected in one family only (Table S1, Supplemental Digital Content 1, http:// links.lww.com/PDR/A43). There is no doubt that GJB2 should be sequenced first in each hearing impaired individual, followed by screening for the large deletion truncating GJB6 in all the Ashkenazi deaf in which GJB2 was ruled out. Today, it is tedious and not cost-effective to screen the known genes in Israel routinely after mutations in GJB2/GJB6 are ruled out. Therefore, we suggest a diagnostic algorithm (Fig. 1) for Jewish individuals presenting with HL, depending on the mode of inheritance, ethnic origin, and clinical/audiological manifestation, and taking into account the most cost-efficient method to address the molecular diagnoses available today. Furthermore, other genes that have been implicated in HL in other parts of the world but not yet found in Israel should be considered when the relevant phenotype is discovered. For example, inherited in a dominant form for nonsyndromic deafness, WFS1 mutations are associated with low frequency HL (56). Patients with dominant $\mathrm{COCH}$ mutations have a characteristic vestibular dysfunction that is similar to Meniere's disease and is associated with HL that begins in the third decade, with high frequencies affected first (57). If aminoglycosidase damage is suspected, the mitochondrial 12S rRNA mutation should be examined, particularly if the HL appears to

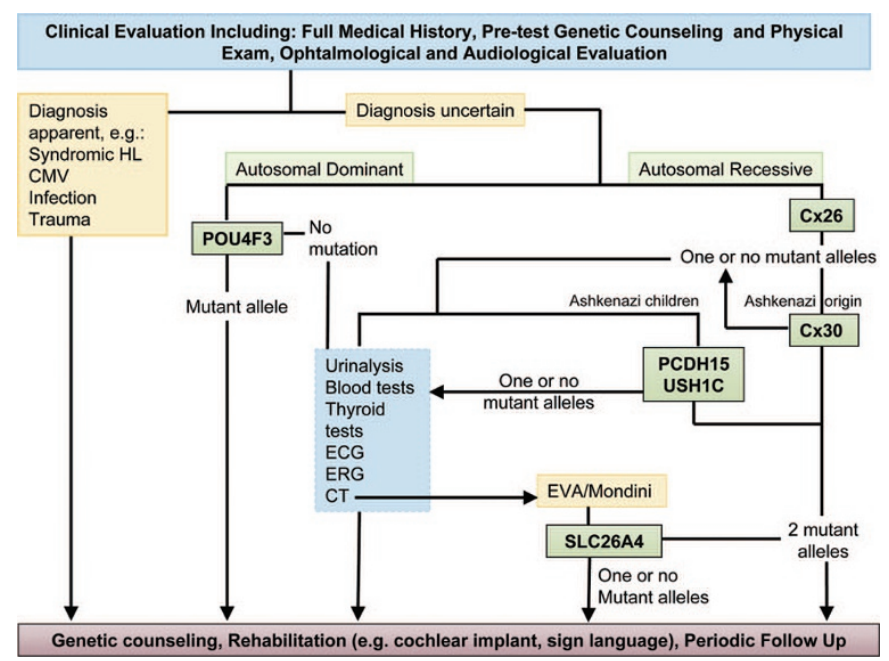

Figure 1. A flow chart demonstrating a diagnostic algorithm for hearing impaired individuals in Israel. The clinical evaluation includes a full medical history and physical exam, as well as ophtalmologic and audiologic evaluations. This chart is a model for other populations, demonstrating the relevance of diagnosing the molecular basis of HL and its application to treatment of patients. follow a maternal form of inheritance (58). TECTA mutations may be responsible when prelingual, nonprogressive, midfrequency hearing impairment is observed (59). Recessive auditory neuropathy, characterized by the absence of detectable responses to auditory evoked potentials (AEP) and the presence of bilateral TEOAE, may be associated with mutations in the OTOF gene $(60,61)$. The identification of genes in the world is a dynamic process, with new genes and mutations being found monthly. Therefore, the literature and the Hereditary Hearing Loss Homepage should be scrutinized routinely to determine whether there are additional genes that should be examined in a patient presenting with suspected genetic hearing impairment. In the future, DNA arrays may be designed that will make screening multiple genes/variants more cost efficient. Furthermore, as we gain knowledge of a complete repertoire of genes involved in hearing, and technology advances, the approach to future treatment and intervention will change accordingly. In particular, there is promise for gene and cell therapy $(62,63)$ with this increased knowledge and advanced tools, and the future holds great promise for the hearing impaired population.

Acknowledgments. We thank all the families who contributed to the studies described in this review, without whom this work could not have taken place. Their participation in the study enabled many more families to learn about their genetic basis of HL. We also thank our collaborators over the years that have been involved in patient ascertainment and gene identification and contributed an essential component to the success of this work. We especially thank Prof. Moshe Frydman, a devoted clinician and researcher, whose guidance and dedication has carried us throughout this project.

\section{REFERENCES}

1. Nadol JB Jr 1993 Hearing loss. N Engl J Med 329:1092-1102

2. Khabori MA, Patton MA 2008 Consanguinity and deafness in Omani children. Int J Audiol 47:30-33

3. Sajjad M, Khattak AA, Bunn JE, Mackenzie I 2008 Causes of childhood deafness in Pukhtoonkhwa Province of Pakistan and the role of consanguinity. J Laryngol Otol 122:1057-1063

4. Morton NE 1991 Genetic epidemiology of hearing impairment. Ann N Y Acad Sci 630:16-31

5. Nance WE 2003 The genetics of deafness. Ment Retard Dev Disabil Res Rev 9:109-119

6. Gorlin RJ, Toriello HV, Cohen MM 1995 Hereditary Hearing Loss and its Syndromes. Oxford University Press, Oxford

7. Sobe T, Vreugde S, Shahin H, Berlin M, Davis N, Kanaan M, Yaron Y, Orr-Urtreger A, Frydman M, Shohat M, Avraham KB 2000 The prevalence and expression of inherited connexin 26 mutations associated with nonsyndromic hearing loss in the Israeli population. Hum Genet 106:50-57

8. Boughman JA, Vernon M, Shaver KA 1983 Usher syndrome: definition and estimate of prevalence from two high-risk populations. J Chronic Dis 36:595-603

9. Hope CI, Bundey S, Proops D, Fielder AR 1997 Usher syndrome in the city of Birmingham - prevalence and clinical classification. Br J Ophthalmol 81:46-53

10. Van Camp G, Willems PJ, Smith RJ 1997 Nonsyndromic hearing impairment: unparalleled heterogeneity. Am J Hum Genet 60:758-764

11. Bitner-Glindzicz M, Pembrey M, Duncan A, Heron J, Ring SM, Hall A, Rahman S 2009 Prevalence of mitochondrial 1555A-> G mutation in European children. N Engl J Med 360:640-642

12. Vandebona H, Mitchell P, Manwaring N, Griffiths K, Gopinath B, Wang JJ, Sue CM 2009 Prevalence of mitochondrial 1555A-> G mutation in adults of European descent. N Engl J Med 360:642-644

13. Estivill X, Govea N, Barcelo E, Badenas C, Romero E, Moral L, Scozzri R, D'Urbano L, Zeviani M, Torroni A 1998 Familial progressive sensorineural deafness is mainly due to the mtDNA A1555G mutation and is enhanced by treatment of aminoglycosides. Am J Hum Genet 62:27-35

14. Petersen MB, Willems PJ 2006 Non-syndromic, autosomal-recessive deafness. Clin Genet 69:371-392

15. Del Castillo I, Moreno-Pelayo MA, Del Castillo FJ, Brownstein Z, Marlin S, Adina Q, Cockburn DJ, Pandya A, Siemering KR, Chamberlin GP, Ballana E, Wuyts W, 
Maciel-Guerra AT, Alvarez A, Villamar M, Shohat M, Abeliovich D, Dahl HH, Estivill X, Gasparini P, Hutchin T, Nance WE, Sartorato EL, Smith RJ, Van Camp G, Avraham KB, Petit C, Moreno F 2003 Prevalence and evolutionary origins of the del(GJB6-D13S1830) mutation in the DFNB1 locus in hearing-impaired subjects: a multicenter study. Am J Hum Genet 73:1452-1458

16. Walsh T, Walsh V, Vreugde S, Hertzano R, Shahin H, Haika S, Lee MK, Kanaan M, King MC, Avraham KB 2002 From flies' eyes to our ears: mutations in a human class III myosin cause progressive nonsyndromic hearing loss DFNB30. Proc Natl Acad Sci USA 99:7518-7523

17. Brownstein ZN, Dror AA, Gilony D, Migirov L, Hirschberg K, Avraham KB 2008 A novel SLC26A4 (PDS) deafness mutation retained in the endoplasmic reticulum. Arch Otolaryngol Head Neck Surg 134:403-407

18. Vahava O, Morell R, Lynch ED, Weiss S, Kagan ME, Ahituv N, Morrow JE, Lee MK, Skvorak AB, Morton CC, Blumenfeld A, Frydman M, Friedman TB, King MC, Avraham KB 1998 Mutation in transcription factor POU4F3 associated with inherited progressive hearing loss in humans. Science 279:1950-1954

19. Brownstein Z, Goldfarb A, Levi H, Frydman M, Avraham KB 2006 Chromosomal mapping and phenotypic characterization of hereditary otosclerosis linked to the OTSC4 locus. Arch Otolaryngol Head Neck Surg 132:416-424

20. Brownstein Z, Friedlander Y, Peritz E, Cohen T 1991 Estimated number of loci for autosomal recessive severe nerve deafness within the Israeli Jewish population, with implications for genetic counseling. Am J Med Genet 41:306-312

21. Kelley PM, Abe S, Askew JW, Smith SD, Usami S, Kimberling WJ 1999 Human connexin $30(G J B 6)$, a candidate gene for nonsyndromic hearing loss: molecular cloning, tissue-specific expression, and assignment to chromosome 13q12. Genomics 62:172-176

22. Forge A, Becker D, Casalotti S, Edwards J, Marziano N, Nevill G 2003 Gap junctions in the inner ear: comparison of distribution patterns in different vertebrates and assessment of connexin composition in mammals. J Comp Neurol 467:207-231

23. Forge A, Becker D, Casalotti S, Edwards J, Evans WH, Lench N, Souter M 1999 Gap junctions and connexin expression in the inner ear. Novartis Found Symp 219:134-150; discussion 151-136

24. Beltramello M, Piazza V, Bukauskas FF, Pozzan T, Mammano F 2005 Impaired permeability to Ins $(1,4,5) \mathrm{P} 3$ in a mutant connexin underlies recessive hereditary deafness. Nat Cell Biol 7:63-69

25. Grifa A, Wagner CA, D’Ambrosio L, Melchionda S, Bernardi F, Lopez-Bigas N, Rabionet R, Arbones M, Monica MD, Estivill X, Zelante L, Lang F, Gasparini P 1999 Mutations in GJB6 cause nonsyndromic autosomal dominant deafness at DFNA3 locus. Nat Genet 23:16-18

26. Dahl E, Manthey D, Chen Y, Schwarz HJ, Chang YS, Lalley PA, Nicholson BJ, Willecke K 1996 Molecular cloning and functional expression of mouse connexin30, a gap junction gene highly expressed in adult brain and skin. J Biol Chem 271:17903-17910

27. Denoyelle F, Marlin S, Weil D, Moatti L, Chauvin P, Garabedian EN, Petit C 1999 Clinical features of the prevalent form of childhood deafness, DFNB1, due to a connexin-26 gene defect: implications for genetic counselling. Lancet 353:1298-1303

28. Kelsell DP, Dunlop J, Stevens HP, Lench NJ, Liang JN, Parry G, Mueller RF, Leigh IM 1997 Connexin 26 mutations in hereditary non-syndromic sensorineural deafness. Nature 387:80-83

29. Lerer I, Sagi M, Malamud E, Levi H, Raas-Rothschild A, Abeliovich D 2000 Contribution of connexin 26 mutations to nonsyndromic deafness in Ashkenazi patients and the variable phenotypic effect of the mutation 167delT. Am J Med Genet 95:53-56

30. Lerer I, Sagi M, Ben-Neriah Z, Wang T, Levi H, Abeliovich D 2001 A deletion mutation in GJB6 cooperating with a GJB2 mutation in trans in non-syndromic deafness: a novel founder mutation in Ashkenazi Jews. Hum Mutat 18:460

31. Del Castillo I 2002 A deletion involving the connexin 30 gene in nonsyndromic hearing impairment. N Engl J Med 346:243-249

32. Pallares-Ruiz N, Blanchet P, Mondain M, Claustres M, Roux AF 2002 A large deletion including most of GJB6 in recessive non syndromic deafness: a digenic effect? Eur J Hum Genet 10:72-76

33. Common JE, Bitner-Glindzicz M, O'Toole EA, Barnes MR, Jenkins L, Forge A, Kelsell DP 2005 Specific loss of connexin 26 expression in ductal sweat gland epithelium associated with the deletion mutation del(GJB6-D13S1830). Clin Exp Dermatol 30:688-693

34. Snoeckx RL, Huygen PL, Feldmann D, Marlin S, Denoyelle F, Waligora J, MuellerMalesinska M, Pollak A, Ploski R, Murgia A, Orzan E, Castorina P, Ambrosetti U, Nowakowska-Szyrwinska E, Bal J, Wiszniewski W, Janecke AR, Nekahm-Heis D, Seeman P, Bendova O, Kenna MA, Frangulov A, Rehm HL, Tekin M, Incesulu A, Dahl HH, du Sart D, Jenkins L, Lucas D, Bitner-Glindzicz M, Avraham KB, Brownstein Z, del Castillo I, Moreno F, Blin N, Pfister M, Sziklai I, Toth T, Kelley PM, Cohn ES, Van Maldergem L, Hilbert P, Roux AF, Mondain M, Hoefsloot LH, Cremers CW, Lopponen T, Lopponen H, Parving A, Gronskov K, Schrijver I, Roberson J, Gualandi F, Martini A, Lina-Granade G, Pallares-Ruiz N, Correia C, Fialho G, Cryns K, Hilgert N, Van de Heyning P, Nishimura CJ, Smith RJ, Van Camp G 2005 GJB2 mutations and degree of hearing loss: a multicenter study. Am J Hum Genet 77:945-957

35. Albert S, Blons H, Jonard L, Feldmann D, Chauvin P, Loundon N, Sergent-Allaoui A, Houang M, Joannard A, Schmerber S, Delobel B, Leman J, Journel H, Catros H, Dollfus H, Eliot MM, David A, Calais C, Drouin-Garraud V, Obstoy MF, Tran Ba Huy P, Lacombe D, Duriez F, Francannet C, Bitoun P, Petit C, Garabedian EN, Couderc R, Marlin S, Denoyelle F 2006 SLC26A4 gene is frequently involved in nonsyndromic hearing impairment with enlarged vestibular aqueduct in Caucasian populations. Eur J Hum Genet 14:773-779

36. Alagramam KN, Yuan H, Kuehn MH, Murcia CL, Wayne S, Srisailpathy CR, Lowry RB, Knaus R, Van Laer L, Bernier FP, Schwartz S, Lee C, Morton CC, Mullins RF, Ramesh A, Van Camp G, Hageman GS, Woychik RP, Smith RJ, Hagemen GS 2001
Mutations in the novel protocadherin $\mathrm{PCDH} 15$ cause Usher syndrome type 1F. Hum Mol Genet 10:1709-1718

37. Ahmed ZM, Riazuddin S, Bernstein SL, Ahmed Z, Khan S, Griffith AJ, Morell RJ, Friedman TB, Wilcox ER 2001 Mutations of the protocadherin gene PCDH15 cause Usher syndrome type 1F. Am J Hum Genet 69:25-34

38. Alagramam KN, Murcia CL, Kwon HY, Pawlowski KS, Wright CG, Woychik RP 2001 The mouse Ames Waltzer hearing-loss mutant is caused by mutation of Pcdh15, a novel protocadherin gene. Nat Genet 27:99-102

39. Kazmierczak P, Sakaguchi H, Tokita J, Wilson-Kubalek EM, Milligan RA, Muller U, Kachar B 2007 Cadherin 23 and protocadherin 15 interact to form tip-link filaments in sensory hair cells. Nature 449:87-91

40. Ben-Yosef T, Ness SL, Madeo AC, Bar-Lev A, Wolfman JH, Ahmed ZM, Desnick RJ, Willner JP, Avraham KB, Ostrer H, Oddoux C, Griffith AJ, Friedman TB 2003 A mutation of $P C D H 15$ among Ashkenazi Jews with the type 1 Usher syndrome. N Engl J Med 348:1664-1670

41. Brownstein Z, Ben-Yosef T, Dagan O, Frydman M, Abeliovich D, Sagi M, Abraham FA, Taitelbaum-Swead R, Shohat M, Hildesheimer M, Friedman TB, Avraham KB 2004 The R245X mutation of $P C D H 15$ in Ashkenazi Jewish children diagnosed with nonsyndromic hearing loss foreshadows retinitis pigmentosa. Pediatr Res 55:995-1000

42. Petit C 2001 Usher syndrome: from genetics to pathogenesis. Annu Rev Genomics Hum Genet 2:271-297

43. Lefevre G, Michel V, Weil D, Lepelletier L, Bizard E, Wolfrum U, Hardelin JP, Petit C 2008 A core cochlear phenotype in USH1 mouse mutants implicates fibrous links of the hair bundle in its cohesion, orientation and differential growth. Development 135:1427-1437

44. Verpy E, Leibovici M, Zwaenepoel I, Liu XZ, Gal A, Salem N, Mansour A, Blanchard S, Kobayashi I, Keats BJ, Slim R, Petit C 2000 A defect in harmonin, a PDZ domain-containing protein expressed in the inner ear sensory hair cells, underlies Usher syndrome type 1C. Nat Genet 26:51-55

45. Zwaenepoel I, Verpy E, Blanchard S, Meins M, Apfelstedt-Sylla E, Gal A, Petit C 2001 Identification of three novel mutations in the USH1C gene and detection of thirty-one polymorphisms used for haplotype analysis. Hum Mutat 17:34-41

46. Erkman L, McEvilly RJ, Luo L, Ryan AK, Hooshmand F, O'Connell SM, Keithley EM, Rapaport DH, Ryan AF, Rosenfeld MG 1996 Role of transcription factors Brn-3.1 and Brn-3.2 in auditory and visual system development. Nature 381:603-606

47. Xiang M, Gan L, Li D, Chen ZY, Zhou L, O'Malley BW Jr, Klein W, Nathans J 1997 Essential role of POU-domain factor Brn-3c in auditory and vestibular hair cell development. Proc Natl Acad Sci USA 94:9445-9450

48. Weiss S, Gottfried I, Mayrose I, Khare SL, Xiang M, Dawson SJ, Avraham KB 2003 The DFNA15 deafness mutation affects POU4F3 protein stability, localization, and transcriptional activity. Mol Cell Biol 23:7957-7964

49. Frydman M, Vreugde S, Nageris BI, Weiss S, Vahava O, Avraham KB 2000 Clinical characterization of genetic hearing loss caused by a mutation in the POU4F3 transcription factor. Eur Arch Otorhinolaryngol 126:633-637

50. Collin RW, Chellappa R, Pauw RJ, Vriend G, Oostrik J, van Drunen W, Huygen PL, Admiraal R, Hoefsloot LH, Cremers FP, Xiang M, Cremers CW, Kremer H 2008 Missense mutations in POU4F3 cause autosomal dominant hearing impairment DFNA15 and affect subcellular localization and DNA binding. Hum Mutat 29:545-554

51. Goh JP, Chan LL, Tan TY 2002 MRI of cochlear otosclerosis. Br J Radiol 75:502-505

52. Lopez-Gonzalez MA, Delgado F 2000 Oral vaccine in otosclerosis. Med Hypotheses 54:216-220

53. Sakihara Y, Parving A 1999 Clinical otosclerosis, prevalence estimates and spontaneous progress. Acta Otolaryngol 119:468-472

54. Zhao F, Wada H, Koike T, Ohyama K, Kawase T, Stephens D 2002 Middle ear dynamic characteristics in patients with otosclerosis. Ear Hear 23:150-158

55. Vartiainen E 1999 Sex differences in patients with hearing impairments caused by otosclerosis. Eur Arch Otorhinolaryngol 256:431-433

56. Young TL, Ives E, Lynch E, Person R, Snook S, MacLaren L, Cater T, Griffin A, Fernandez B, Lee MK, King MC 2001 Non-syndromic progressive hearing loss DFNA38 is caused by heterozygous missense mutation in the Wolfram syndrome gene WFS1. Hum Mol Genet 10:2509-2514

57. Robertson NG, Lu L, Heller S, Merchant SN, Eavey RD, McKenna M, Nadol JB Jr, Miyamoto RT, Linthicum FH Jr, Lubianca Neto JF, Hudspeth AJ, Seidman CE, Morton CC, Seidman JG 1998 Mutations in a novel cochlear gene cause DFNA9, a human nonsyndromic deafness with vestibular dysfunction. Nat Genet 20:299-303

58. Prezant TR, Agapian JV, Bohlman MC, Bu X, Oztas S, Qiu WQ, Arnos KS, Cortopassi GA, Jaber L, Rotter JI, Shohat M, Fischel-Ghodsian N 1993 Mitochondrial ribosomal RNA mutation associated with both antibiotic-induced and nonsyndromic deafness. Nat Genet 4:289-294

59. Verhoeven K, Van Laer L, Kirschhofer K, Legan PK, Hughes DC, Schatteman I, Verstreken M, Van Hauwe P, Coucke P, Chen A, Smith RJ, Somers T, Offeciers FE, Van de Heyning P, Richardson GP, Wachtler F, Kimberling WJ, Willems PJ, Govaerts PJ, Van Camp G 1998 Mutations in the human alpha-tectorin gene cause autosomal dominant non-syndromic hearing impairment. Nat Genet 19:60-62

60. Varga R, Kelley PM, Keats BJ, Starr A, Leal SM, Cohn E, Kimberling WJ 2003 Non-syndromic recessive auditory neuropathy is the result of mutations in the otoferlin (OTOF) gene. J Med Genet 40:45-50

61. Rodriguez-Ballesteros M, del Castillo FJ, Martin Y, Moreno-Pelayo MA, Morera C, Prieto F, Marco J, Morant A, Gallo-Teran J, Morales-Angulo C, Navas C, Trinidad G, Tapia MC, Moreno F, del Castillo I 2003 Auditory neuropathy in patients carrying mutations in the otoferlin gene (OTOF). Hum Mutat 22:451-456

62. Martinez-Monedero R, Oshima K, Heller S, Edge AS 2007 The potential role of endogenous stem cells in regeneration of the inner ear. Hear Res 227:48-52

63. Raphael Y, Kim YH, Osumi Y, Izumikawa M 2007 Non-sensory cells in the deafened organ of Corti: approaches for repair. Int J Dev Biol 51:649-654 